REFLECTIONS:

NEUROLOGY AND THE

HUMANITIES

Section Editor

Michael H. Brooke, MD

\section{The Decision}

Raphael Arellano Carandang, MD

Faced with

the worsening deficits of neuronal destruction

or

a catastrophic hemorrhage of iatrogenic over aggression

the electrical chaos of synchronized periodic neuronal firing

or

the perils of invasive intervention and its attendant complications

shall we

an existence of utter dependency

or

the certain unknown of oblivion

the emotional pull of a lifelong companion

or

the increasingly burdensome economics of a society

to navigate the precarious knowledge of the present

always advocating for the other

taking every care to avoid harm call on the hubris of past experience

or

use the limited scope of current evidence

to determine the path to take

will continuing study ever produce data applicable to every circumstance?

or

does it ultimately fall on individual discernment?

we cannot take lightly the outcome of the other

as we assume the mantle of the determiner

yet all fades to

grey

and we are still left with

the

choice 


\title{
Neurology
}

\author{
The Decision \\ Raphael Arellano Carandang \\ Neurology 2008;70;2085 \\ DOI 10.1212/01.wnl.0000316766.79769.66
}

This information is current as of May 27, 2008

\section{Updated Information \&} Services

Permissions \& Licensing

Reprints including high resolution figures, can be found at: http://n.neurology.org/content/70/22/2085.full

Information about reproducing this article in parts (figures,tables) or in its entirety can be found online at:

http://www.neurology.org/about/about_the_journal\#permissions

Information about ordering reprints can be found online:

http://n.neurology.org/subscribers/advertise

Neurology ${ }^{\circledR}$ is the official journal of the American Academy of Neurology. Published continuously since 1951, it is now a weekly with 48 issues per year. Copyright . All rights reserved. Print ISSN: 0028-3878. Online ISSN: 1526-632X.

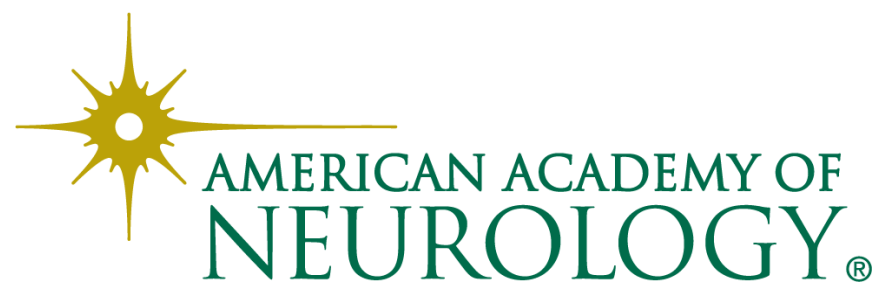

